\title{
TATA LAKSANA PEMBELAJARAN PENDIDIKAN JASMANI OLAHRAGA DAN KESEHATAN
}

\section{PROCEDURE OF SPORTS AND HEALTH PHYSICAL EDUCATION}

\author{
${ }^{1}$ Aswan Dai, ${ }^{2}$ Sarjan Mile, ${ }^{3}$ Moh. Irfan, ${ }^{4 *}$ Hartono Hadjarati \\ ${ }^{1,2,3}$ Pendidikan Jasmani Kesehatan dan Rekreasi, Fakultas Olahraga dan Kesehatan Universitas Negeri Gorontalo \\ ${ }^{4 *}$ Pendidikan Kepelatihan Olahraga, Fakultas Olahraga dan Kesehatan Universitas Negeri Gorontalo
}

Kontak koresponden: hartonohadjarati@ung.ac.id

\begin{abstract}
ABSTRAK
Tujuan yang ingin dicapai dari penelitian ini, adalah untuk mengetahui proses pembelajaran PJOK (Pendidikan Jasmani Olahraga dan Kesehatan) pada masa pandemik. Penelitian ini menggunakan pendekatan kualitatif. Pendekatan kualitatif salah satu teknik yang mengambarkan dan menginterprestasikan arti data-data yang terkumpul dengan memberikan perhatian dan merekam sebanyaknya, mungkin aspek situasi yang diteliti pada saat itu sehingga memperoleh gambaran, secara umum, dan menyeluruh tentang keadaan sebenarnya. Hasil penelitian menunjukan Berdasarkan hasil penelitian yang telah diperoleh di SMP Se-Kecamatan Suwawa mengenai Pembelajaran PJOK, pembelajaran daring yang dilakukan oleh guru terutama guru mata pelajaran pendidikan jasmani, tetap dilaksnanakan walaupun pembelajaran daring ini tidak seefektif dengan pembelajaran tatap muka langsung. Kemudian juga Antusias atau partisipasi belajar siswa di SMP se-Kecamatan Suwawa yang kurang baik dikarenakan dalam mengikuti pembelajaran daring siswa cepat bosan dan juga karena data internet yang dimiliki oleh siswa itu kurang dalam mengikuti pembelajaran daring, bukan hanya pembelajaran PJOK saja tetapi ada banyak jadwal pembelajaran setiap hari yang di ikuti oleh siswa SMP Se-Kecamatan. Tidak seperti sebelumnya artinya sebelum dilakukannnya pembelajaran daring pembelajaran pendidikan jasmani itu sangat baik, mungkin karena pembelajaran dilakukan di sekolah secara tatap muka langsung juga fasilitas yang lengkap dan juga siswa mudah di kontrol oleh guru.
\end{abstract}

Kata Kunci: tata laksana; pembelajaran PJOK

\section{ABSTRACT}

The aim of this research is to find out the PJOK (Sports Physical Education and Health) learning process during a pandemic. This study uses a qualitative approach. A qualitative approach is a technique that describes and interprets the meaning of the data collected by paying attention and recording as many as possible aspects of the situation being studied at that time so as to obtain a general and comprehensive picture of the actual situation. The results show that based on the results of research that has been obtained in SMP throughout Suwawa District regarding PJOK Learning, online learning carried out by teachers, especially teachers of physical education subjects, is still carried out even though online learning is not as effective as face-to-face learning. Then also Enthusiasm or student learning participation in junior high schools throughout Suwawa District which is not good because in participating in online learning students get bored quickly and also because the internet data owned by students is lacking in participating in online learning, not only PJOK learning but there are 
many learning schedules every day that is followed by junior high school students in all subdistricts. Unlike before, it means that prior to online learning, physical education learning was very good, maybe because learning was carried out in schools face-to-face with complete facilities and also students were easily controlled by the teacher.

\section{Keywords: procedure; PJOK learning}

\section{Pendahuluan}

Development in a country is an obligation in advancing the next generations of the nation. One of the efforts in carrying out this obligation is education. Education is a very important asset for the State. Education is a very important need because it is one of the sectors for the progress of the country (Aziizu, 2015). Educational institutions are expected to be able to make breakthroughs to bring Indonesia not behind other countries (Mulya, 2018).

Education is one of the institutions that is expected to improve the quality of human resources (Margaretha \& Simanjuntak, 2020). Education can and should therefore contribute to a new vision of sustainable global development. A well-executed education also has a good impact on national development. To achieve the goals of national education, it is necessary to have mature efforts in preparing good plans, approaches, and strategies.

In essence, in the world of education, it is important to ensure that a good, interesting and systematic learning process is implemented, which involves all aspects of the learning process, namely involving teachers, students, facilities and infrastructure so as to create direct interaction between teachers and students (Clausen et al., 2019). A good learning process will occur because of the interaction between a teacher and his environment (Kadir et al., 2021; Lamusu \& Lamusu, 2021). The reality at this time in the world of education sometimes there are obstacles or problems in the implementation of the learning process. This problem can arise from teachers, students, infrastructure or other aspects in the school (Mashud, 2019; Syed et al., 2017). This of course has a negative impact on success in the implementation of the learning process.

In education there is a lot of learning to be done. One of them is physical education, sports and health (PJOK). Physical education, sports and health are an integral part of overall education, aiming to develop aspects of physical fitness, movement skills, critical thinking skills, social skills, reasoning, emotional stability, moral action, aspects of a healthy lifestyle and introduction of a clean environment through physical activity, selected sports and health that are planned systematically in order to achieve national education goals (Diharjo \& Wiguno, 2021; Mustafa \& Dwiyogo, 2020).

At the beginning of 2020, to be precise, in early March, Indonesia was faced with an outbreak or virus that was very dangerous to human health in the world. The virus is called the Corona virus or often referred to as Covid-19 (Indartono et al., 2020). The existence of this virus has a negative impact on everyday life, both in the fields of education, economy, social and culture (Abidin \& Tobibatussa'adah, 2021; Siahaan, 2020). The impact of the Covid-19 outbreak can be seen in almost all areas of people's lives. Especially the impact on the world of 
education. Prohibition and temporary cessation of social activities, weakening of the economy, reduced transportation services and strict supervision, closure of tourism, shopping centers for tourists and vacancies in the informal sector such as online motorcycle taxis, city transportation drivers, street vendors, traveling traders, MSMEs and manual workers experienced a reduction income.

The Covid-19 pandemic has greatly impacted education in the world, especially in Indonesia. This outbreak has resulted in the learning process that was previously carried out in person or face-to-face in schools to become online or online learning carried out from their respective homes that utilize technology, information and communication. With the Covid-19 pandemic, the Ministry of Health issued the Minister of Health Regulation Number 9 of 2020 concerning Large-Scale Social Restrictions, one of which is the elimination of face-to-face teaching and learning activities in schools. With the enactment of the PSBB, the solution given to carry out teaching and learning activities is distance learning. Distance learning utilizes the latest technology using information technology media.

This online or online learning greatly affects the process of implementing physical education, sports and health (PJOK) in schools. Because the PJOK learning process is generally carried out in theory with practice (Ardonansyah et al., 2021). In general, PJOK learning which is dominated by physical movement is carried out in open spaces or in the field (Gustiawati \& Julianti, 2018). The method for learning PJOK is the deductive method or the command method, with a variety of assignments, demonstrations and a little explanation (Pranoto \& Suprayogi, 2020). Therefore, the Covid-19 pandemic has a very negative impact on the implementation of the PJOK learning process.

The urgency of this research is that there are many obstacles faced by educators and students. Various limitations such as internet access and operational capabilities on online features, physical education naturally encountered various obstacles and obstacles during the covid-19 pandemic. This has a very big impact on PJOK learning in Indonesia, namely learning that should be in accordance with RPP carried out with theoretical and practical learning, is not

fulfilled properly, this situation makes the author interested in conducting research related to the implementation of PJOK learning carried out by online learning or online. The previous research conducted at the high school 1 Nganjuk (Rokim, 2016) certainly different from this research which was conducted in junior high schools and also in different locations.

\section{Metode}

Place This research was conducted in junior high schools in Suwawa District, Bone Bolango Regency, Gorontalo Province. This study uses a qualitative approach. Qualitative research is a process of exploring and understanding the meaning of the behavior of each person and group, describing social problems or human problems. This study has data sources related to junior high schools in Suwawa District, Bone Bolango Regency, Gorontalo Province consisting of the Principal, PJOK teachers and students.

Data collection was carried out in natural settings, primary data sources, and data collection techniques were more on participatory observation, in-depth interviews, and 
documentation. Data analysis is done by organizing the data, breaking it down into units, synthesizing it, arranging it into a pattern, choosing what is important and what will be studied, and making conclusions that can be told to others. Then do the data poleulation to determine the validity of the data

\section{Hasil}

PJOK learning at State Junior High Schools in Suwawa District before the pandemic was running as it should, where teachers and students practiced in the field or face to face. After the corona virus outbreak, learning in schools began to be abolished and learning was also carried out online, using learning applications such as class rooms, google meet, and also via zoom and some students visited their homes.

After a disaster struck in our country, namely the Corona virus or commonly referred to as Covid19, it had an impact on all activities related to crowds, especially in the learning process at schools, especially PJOK learning in State Junior High Schools in the Suwawa District. From the beginning of this covid19 pandemic, teachers, especially sports teachers, have conducted online learning, the Sports Teacher said specifically for PJOK there are only a few students who take part in this online learning. And there are also those who are visited at their homes and during a pandemic, such as the results of student competence, especially sports, which are not satisfactory.

The form and encouragement of teachers, especially sports, provide motivation to students so that students continue to do activities as they should. Always get up early and then do the next activity, special PJOK learning activities during the current pandemic, we usually do activities well, meaning students are familiar with the activities being carried out, PJOK teachers also monitor students themselves when doing classroom learning.

Based on the analysis of the research results, the role of the government is the main factor in the implementation of this online learning. In addition to the government, the role of teachers is needed so that students can learn effectively and can improve their learning outcomes even though the government implements online learning.

Based on the results of the research in general, it shows that in SMP throughout Suwawa District the PJOK learning process runs well and smoothly in accordance with the curriculum that has been made, namely the 2013 curriculum, where the learning carried out by the teacher is in accordance with the material.

Based on the results of research that has been obtained in junior high schools in Suwawa District regarding PJOK Learning, online learning carried out by teachers, especially teachers of physical education subjects, is still carried out even though online learning is not as effective as face-to-face learning. Then also Enthusiasm or student learning participation in junior high schools throughout Suwawa District which is not good because in participating in online learning students get bored quickly and also because the internet data owned by students is lacking in participating in online learning, not only PJOK learning but there are many learning schedules every day that is followed by junior high school students in all sub-districts. Unlike before, it means that prior to online learning, physical education learning was very good, maybe because 
learning was carried out in schools face-to-face with complete facilities and also students were easily controlled by the teacher.

As for the supporting factors in PJOK learning at junior high schools in Suwawa subdistrict, PJOK teachers do not tire of giving direction and motivation to students to stay patient and follow PJOK learning well and also teachers always remind to keep exercising so that the body stays healthy. although online learning in schools is not good, especially in PJOk learning, the willingness of students to take part in online learning continues to run well until now.

In addition to supporting factors, there are also inhibiting factors in learning PJOK at SMP in Suwawa District, especially the very dangerous disease, namely covid-19, the unavailability of facilities used by students when learning PJOK at home and also the lack of internet data for students who are praying. a barrier to learning.

\section{Pembahasan}

In general, it shows that in SMP in Suwawa District, the PJOK learning process runs well and smoothly. The indication is that students in general can use mobile learning well (Ahmad Sasmito et al., 2021), so the teacher in delivering the material is not too much of an obstacle. Giving assignments can also be done so that feedback from students can occur. Online learning carried out by teachers, especially teachers of physical education subjects, is still carried out with the help of online features that support the teaching and learning process, such as Google Form, Google Meet, and Zoom.

Supporting factors in PJOK learning in junior high schools in Suwawa sub-district, PJOK teachers do not tire of giving direction and motivation to students to remain patient and follow PJOK learning well. Motivation is important as an effort to encourage students to be able to follow learning well from home (Izzatunnisa et al., 2021). The inhibiting factors in learning PJOK in junior high schools throughout the Suwawa sub-district are disease and the availability of facilities which sometimes often take turns with other family members.

\section{Kesimpulan}

Based on research on the PJOK Student Survey in the Covid-19 Pandemic Period at SMP in Suwawa District, it can be concluded that PJOK learning at SMP in Suwawa District is not good, because the learning carried out during the current pandemic is different from before. The learning carried out by junior high schools in Suwawa District in the period before the pandemic was that they carried out direct or face-to-face practice, was inversely proportional to the corona virus outbreak, namely online learning or online learning, where students studied online and offline due to the corona virus disease or covid. -19 that hit almost the whole world. Even though online learning is not optimal, online learning continues to this day.

\section{Referensi}

Abidin, Z., \& Tobibatussa'adah, T. (2021). The Impact Of Covid-19 Pandemicon Education And Judicial Practicein Indonesia. Ri'ayah: Jurnal Sosial Dan Keagamaan, 5(02). https://doi.org/10.32332/riayah.v5i02.2794 
Ahmad Sasmito, D., Yusrotin, A., \& Shaherani, N. (2021). Implementasi Mobile Learning Sebagai Solusi Pembelajaran Online Akibat Pandemi Covid-19 Di SMA Negeri 1 Singosari. Indonesian Journal of Sociology, Education, and Development, 3(1). https://doi.org/10.52483/ijsed.v3i1.45

Ardonansyah, M., Hardiyono, B., \& Hidayat, A. (2021). Motivasi Peserta Didik Sekolah Dasar Dalam Pembelajaran Pendidikan Jasmani Olahraga Dan Kesehatan Selama Masa Pandemi. Journal Coaching Education Sports, 2(2). https://doi.org/10.31599/jces.v2i2.739

Aziizu, B. Y. A. (2015). Tujuan Besar Pendidikan Adalah Tindakan. Prosiding Penelitian Dan Pengabdian Kepada Masyarakat, 2(2). https://doi.org/10.24198/jppm.v2i2.13540

Clausen, L. P. W., Mendoza, R., Bazylak, J., \& Hansen, S. F. (2019). Comparative analysis of two teaching methods for large classes. ASEE Annual Conference and Exposition, Conference Proceedings. https://doi.org/10.18260/1-2--32522

Diharjo, M. Z., \& Wiguno, L. T. H. (2021). Pilihan Materi Pembelajaran Guru Pjok SMA dalam Memenuhi Tuntutan Kompetensi Dasar Kurikulum 2013. Sport Science and Health, 3(3). https://doi.org/10.17977/um062v3i32021p98-106

Gustiawati, R., \& Julianti, R. R. (2018). Pengaruh Model Pendidikan Gerak (Movement Education) Terhadap Hasil Penilaian Kognitif Dalam Pembelajaran Pendidikan Jasmani Olahraga Dan Kesehatan .... Jurnal Speed (Sport, Physical ....

Indartono, S., Asaduddin, A. H., \& Soraya, Y. (2020). The Indonesian citizen behavior in facing covid-19. International Journal of Psychosocial Rehabilitation, 24(9). https://doi.org/10.37200/IJPR/V24I9/PR290036

Izzatunnisa, L., Suryanda, A., Kholifah, A. S., Loka, C., Goesvita, P. P. I., Aghata, P. S., \& Anggraeni, S. (2021). Motivasi Belajar Siswa Selama Pandemi dalam Proses Belajar dari Rumah. Jurnal Pendidikan, 9(2). https://doi.org/10.36232/pendidikan.v9i2.811

Kadir, S. S., Ramadan, G., Haryanto, A. I., Samin, G., Fataha, I., \& Gani, A. A. (2021). The Effect of Squat Training on Long Jump Ability. JUARA: Jurnal Olahraga, 6(1). https://doi.org/10.33222/juara.v6i1.1242

Lamusu, A., \& Lamusu, Z. (2021). Hubungan Panjang Tungkai Dengan Kemampuan Tendangan Sabit Pencak Silat. Jambura Health and Sport Journal, 3(2). https://doi.org/10.37311/jhsj.v3i2.11359

Margaretha, E., \& Simanjuntak, R. A. (2020). Dampak Belanja Sektor Pendidikan Terhadap Kualitas Pendidikan Di Indonesia. INFO ARTHA, 4(2). https://doi.org/10.31092/jia.v4i2.816

Mashud, M. (2019). Analisis Masalah Guru Pjok Dalam Mewujudkan Tujuan Kebugaran Jasmani. Multilateral Jurnal Pendidikan Jasmani Dan Olahraga. https://doi.org/10.20527/multilateral.v17i2.5704

Mulya, G. (2018). Peran Pendidikan Jasmani Dalam Penguatan Pendidikan Karakter Siswa. Jurnal Sains Keolahragaan Dan Kesehatan, 3(1). https://doi.org/10.5614/jskk.2018.3.1.1

Mustafa, P. S., \& Dwiyogo, W. D. (2020). Kurikulum Pendidikan Jasmani, Olahraga, dan 
Kesehatan di Indonesia Abad 21. JARTIKA Jurnal Riset Teknologi Dan Inovasi Pendidikan. https://doi.org/10.36765/jartika.v3i2.268

Pranoto, B. E., \& Suprayogi, S. (2020). A Need Analysis of ESP for Physical Education Students in Indonesia. Premise: Journal of English Education, 9(1). https://doi.org/10.24127/pj.v9i1.2274

Rokim, M. F. N. (2016). Survei Keterlaksanaan Kurikulum 2013 Pada Guru Pjok Di Sma Negeri Se Kabupaten Nganjuk. Jurnal Pendidikan Olahraga Dan Kesehatan, 4(1).

Siahaan, M. (2020). Dampak Pandemi Covid-19 Terhadap Dunia Pendidikan. Jurnal Kajian Ilmiah, 1(1). https://doi.org/10.31599/jki.v1i1.265

Syed, K. S. A., Mohd Faithal, H. H., \& Habib, M. S. (2017). Tekanan Dan Kepuasan Kerja Dalam Kalangan Guru Pendidikan Jasmani. Journal of Global Business and Social Entrepreneurship. 